\title{
Human Resource Forecast and Development Plan to Support Logistics Infrastructure Improvement
}

\author{
P. Indranoi and N. Kecharananta
}

\begin{abstract}
Logistics has become an important tool for improving efficiency of operation, in order to compete nationally and organizationally. It would benefit economics, society, and politics, which would improve quality of living. Moreover, Thailand's dynamic on world stage still needs logistics infrastructure. The study of prediction for logistics human resource and means for improving logistics human resource correspond to investment in national infrastructure and entering ASEAN Economic Community. Its objective is to improve logistics human resource which is an important factor for expansion of logistics which affect the success of organization, society, and country development in logistics. According to a study, it was found that the need for logistics labor in 2014-2017 tends to increase. Preferred characteristics of logistics human resource in operating correspond to the need in business sector and logistics industry. There are 3 characters, including profession; analysis, communication, and technology; and interpersonal relationship and responsibility. There are 4 aspects in guideline for improving logistics human resource, including knowledge; skill; institute and instructor; and profession.
\end{abstract}

Index Terms-Logistics, human resource development, ASEAN economics community.

\section{INTRODUCTION}

Technological development in transportation has made travelling more convenient, which is a basic factor for national security in politics, economics, and society. In order to develop the country and increase competitiveness in world stage with strength, security, and sustainability; since the First National Economic and Social Development Plan until the present one have placed importance on infrastructure development in transportation which connects transportation to logistics system [1].

Infrastructure development in transportation of the country not only increases competitiveness of the country but also prevents economic opportunity loss [2]. Furthermore, entering ASEAN Economic Community would improve efficiency and quality of infrastructure; and logistics system, in order to make value in production and service sector. Also, it would reduce investment from government and transportation cost of the country.

Logistics is the key for economics system since it is an activity which supports and connects resource, information, and finance for domestic and international trade and

Manuscript received January 20, 2015; revised April 15, 2015.

P. Indranoi is with the Thai Air way International Public Company, BKK 10900 Thailand (e-mail: putjai@hotmail.com).

N. Kecharananta was with Suan Dusit Rajabhat University, BKK 10300 Thailand (e-mail: natsdu@ hotmail.com). investment. Also, it is an important cost for organization and business which can affect other activities in economics system. It can be seen from 1,641.9 billion baht of gross logistic cost of Thailand or 14.7 percent of gross domestic product. The cost of transportation is 49.8 percent of gross logistic cost, storage cost is 41.1 percent, and logistics management cost is 9.1, respectively [3].

Since logistics cost tends to increase, public and private sectors have paid more attention to the importance of logistics cost of the country. Thus strategy for driving logistics system has been created. Public and private sectors have worked together to create strategic plan for logistics system development of the country which corresponds to the Eleventh National Economic and Social Development Plan B.E. 2555 - 2559 (A.D. 2012 - 2016), in order to reinforce foundation of the country by building connection at regional level, especially connection development in transportation and logistics system under collaboration in sub-regions by improving transportation service and logistics to be more efficient and meet international standard, improving regulations for human and related product transportation, improving human resource in transportation and logistics business, and connecting domestic production system so as to be ready for entering ASEAN Economic Community [4].

ASEAN Economic Community would make competitiveness of business and industry sectors stronger and make business sector to improve capability for business operation, since combining ASEAN economics as one market and one production base with free product movement, service, investment, and skilled labor. In service trade, a blueprint has been created which allows ASEAN member countries to hold shares in service business at least 70 percent, eliminates limitations for transnational service business, and reduces limitations in skilled labor movement. In 2013, logistics service, especially goods transportation, was rushed to be operated freely.

Logistics system development and entering ASEAN Economic Community have made changes in logistics labor. Ministry of Labor predicts that 1,650,000 labors will be needed; however, 1,219,005 labors could be produced to the market. Thus 500,000 more labors are still needed. As a result, the number of educational institutes which have logistics program and related programs has been increasing continuously. Although educational institutes have opened more programs and courses, quality of the graduates does not correspond to the advance of technology and business sector's need for administrative personnel who have skill in integrative management in logistics knowledge and supply chain. Furthermore, logistics entrepreneurs are unable to use related knowledge and technology to increase efficiency of 
logistics system in workplace [5]. Moreover, there is no motivation for logistics personnel by raising salary to be higher than personnel's in other fields. In other words, the main problem of personnel in logistics is the lack of personnel both quantitative and qualitative.

Human resource development with enough quality needs knowledge, skills, ability, technical understanding, quality labor, profession code of conduct, and enough amounts. They are important factors for expansion of logistics sector, entering ASEAN Economic Community, building transportation routes, and domestic logistics system. Although some of them have been done by public and private sectors, they lack of guidelines for strategic development and unified strategic framework which are necessary for driving logistics personnel development. Appropriate and efficient human resource development would support organization, society, and country development in logistics which needs planning. Thus the researcher was interested to study the prediction of logistics personnel, and propose a guideline for human resource development in logistics which corresponds to the investment in national infrastructure and entering ASEAN Economic Community, in order to help business sector and logistics industry to make value which benefits economic of the country.

\section{OBJECTIVE}

1) To predict the need for logistics labor of Thailand.

2) To study preferred characteristics of human resource which correspond to business sector and logistics industry.

3) To find a means for human resource development in logistics which corresponds to infrastructure development and entering ASEAN Economic Community.

\section{Methodology}

\section{A. Quantitative Methods}

Quantitative research methodology is used to predict logistics need of the country by analyzing production function with regression analysis.

\section{B. Qualitative Methods}

Qualitative research methodology was done by in-depth interview with main informers from organizations relating personnel in logistics, associations or training institute, and educational institutes in logistics; and group discussion, in order to get a correct conclusion and corresponds to objectives of the study.

\section{RESULTS AND DISCUSSION}

\section{A. Prediction on the Need for Logistics Labor}

Prediction on the need for labor was done by analyzing production function. Popular production function is Cobb Douglas Function which focuses on labor and cost variables only, so as to find relationship with economic growth. Input data include gross domestic product, gross capital stock, net capital stock, and people who work in logistics field. According to the regression analysis, the need for labor from 2014-2017 can be predicted by comparing the predicted value gained from the calculation with the predicted value of logistics labor from Ministry of Labor as shown in Table I.

TABLE I: THE PREDICTION OF LABOR

\begin{tabular}{lcccc}
\multicolumn{5}{c}{ TABLE I: THE PREDICTION OF LABOR } \\
\hline \hline \multicolumn{1}{c}{ Year } & $\mathbf{2 0 1 4}$ & $\mathbf{2 0 1 5}$ & $\mathbf{2 0 1 6}$ & $\mathbf{2 0 1 7}$ \\
\hline $\begin{array}{l}\text { GDP } \\
\text { expansion rate } \\
\text { (percent) }\end{array}$ & 5.83 & 5.83 & 5.83 & 5.83 \\
\hline $\begin{array}{l}\text { capital stock } \\
\text { expansion rate } \\
\text { (percent) }\end{array}$ & 3.72 & 3.72 & 3.72 & 3.72 \\
\hline $\begin{array}{l}\text { approximate } \\
\text { value }\end{array}$ & $1,195,888$ & $1,213,929$ & $1,232,242$ & $1,250,833$ \\
\hline $\begin{array}{l}\text { approximate } \\
\text { value } \\
\text { (Ministry of } \\
\text { Labor) }\end{array}$ & $1,227,418$ & $1,235,843$ & $1,243,950$ & $1,253,184$ \\
\end{tabular}

Prediction on the need for labor from 2014-2017 was done by 2 types of factors: labor and cost. The two factors cause changes of gross domestic product of logistics to be in the same direction or have positive relationship. It was found that, in the future, labor in logistics will be needed more. When predicted value, which was calculated by the researcher, was compared with predicted value from Ministry of Labor, it was found that the values were almost the same and the need for labor in logistics tends to be in the same direction.

\section{B. Preferred Characteristics of Human Resource in Logistics}

Characteristics of human resource in logistics which correspond to the need of business sector and industry can be divided into 2 groups: industry entrepreneurs and logistics researchers. The group of entrepreneurs needs both administrative labor in logistics and operating labor. Characteristics which are needed for working in logistics can be categorized into 3 aspects as follows:

1) Profession: possess knowledge, ability, and skills for working in logistics field; be able to analyze and solve problems efficiently; and improve themselves to reach international standard.

2) Analysis, communication, and technology: possess creativity, ability for analyzing situation, knowledge in technology, ability for improving working system, and communicating efficiently.

3) Interpersonal relationship and responsibility: ability for working as a group, leadership, responsibility for themselves and society, ability for planning, and responsibility of self-learning.

TABLE II: PREFERRED CHARACTERISTICS OF HUMAN RESOURCE IN LOGISTICS

\begin{tabular}{cl}
\hline \hline Profession & -Theories and principles of logistics \\
& -Constant specific skill development in logistics \\
\hline Analysis, & -Situation analysis and problem solving \\
communication & -Ability to communicate and make people understand \\
, and & efficiently and using English language, \\
technology & -Adaptation in learning new technology \\
\hline $\begin{array}{c}\text { Interpersonal } \\
\text { relationship and } \\
\text { responsibility }\end{array}$ & -Human relation and working as a team \\
\hline
\end{tabular}


It was found that preferred characteristics of human resource in logistics are that they place importance on logistics activities and be able to apply theories and principles of logistics to operation. Knowledge and ability are necessary for continuous development in the changes and advance of technology in logistics. In addition, they have to be able to analyze and solve problems. Also, they have to use Thai language to communicate with other people to understand efficiently. These are the results of free market, thus important things for driving organization are responsibility, leadership, and interpersonal relationship for working together efficiently.

\section{Means for Human Resource Development in Logistics} for Supporting National Infrastructure and Entering AEC

1) Educational institute: A main organization which produces human resource in logistics diploma, Bachelor's degree, Master's degree, and Doctoral degree, which can be divided into vocational education and higher education.

2) Language and information technology: Communicating with a language accepted in ASEAN and possesses basic knowledge of technology which enough for operation and advance knowledge in logistics technology.

3) Professional standard: Regulations for characteristics and preferred quality for working in logistics as criteria for controlling, monitoring, testing, evaluating, and quality assurance for graduates.

4) Efficiency of labor: Index for working in logistics which comparing with standard of skill, knowledge, and ability of working.

Means for human resource development in logistics have been done continuously. The number of educational institutes in logistics has been increased; however, the number of produced personnel does not correspond to the need of labor market and the quality is lower than the standard. Thus the curriculum, teaching system, standard of personnel in logistics, language and technology development, and infrastructure development are needed to be reconsidered. Furthermore, professional standard in logistics should be created, so as to increase quality of personnel to be accepted at national and international level. Also, efficiency of labor in logistics should be improved by organizing workshop, creating motivation for working, and increase professional standard.

\section{CONCLUSION}

Prediction on the need for logistics labor. The variables used for considering are labor and logistics cost. They make gross domestic product in logistics. When calculating by regression analysis, it would get a growth rate of employment in logistics, which can be used to predict the need for logistics labor. According to the prediction on logistics labor in 2013-2017 from Ministry of Labor, they tend to be in the same direction. According to the production function analysis, it would be lower than Ministry of Labor's prediction which used applied gross domestic product per labor. The standard deviation is 1.46 . The prediction on the need for labor corresponds to the direction of national infrastructure and entering AEC in 2015 which will use market and production base together. Thus labor will be able to move freely. As a result, there are more competitions in logistics labor, because of human resource development in logistics for supporting direction in the future [6]. Thus it needs planning for human resource development in logistics.

Preferred qualifications or characteristics of human resource in logistics which are necessary for operation and correspond to the need of business sector and logistics industry (Watthananonthachai, 2005, and Zhang, 2013) are separated into 3 categories: 1) profession; 2) analysis, communication, and technology (Nanthawiphawong et al, 2007) [7]-[9]; and 3) interpersonal relationship and responsibility [10], [11]. In operation, application of principles and theories in logistics is necessary. Human resource in logistics must possess professional ability and standard, and improve specific skill constantly. Furthermore, they must be able to analyze situation and solve problem while working. Entering AEC needs efficient communication to make other people understand. They need to adapt with new environment in ASEAN, labor market which has diversity, and working with international standard for working in ASEAN countries. In addition, learning technology in logistics is also important for working continuously. It needs collaboration from people inside organization, thus human resource in logistics must be able to work as a team, possess leadership, and responsibility.

According to quantitative and qualitative assessments on personnel, it was found that problems of human resource development, logistics development for entering AEC, and means for human resource development, reflect situation of personnel production in logistics at present which meets the need. Thus the researcher has proposed means for human resource development in 4 aspects, including knowledge, skill, institute and instructor, and profession with short-term and long-term operation as follows in Tables II, III, and IV.

Human resource development in logistics is separated into 4 aspects: knowledge, skill, institute and instructor, and profession, which is short-term and long-term operation. Human resource in logistics in production sector and educational sector receive development differently. In knowledge aspect, personnel's potential in logistics need to be increased by training, in order to work more efficiently. On the other hand, public sector needs to encourage entrepreneurs or chief executives to understand logistics system, realize the importance of logistics, have knowledge and understanding in logistics work, be able to plan logistics work of organization systematically and efficiently. After that, they entrepreneurs or chief executive must be encouraged to place importance on training for personnel, and create collaboration between industry and training institute, in order to create a guideline for training which corresponds to real operation. Finally, entrepreneurs should be promoted to know about law and regulations relating domestic and international logistics; and promote publicizing logistics knowledge and supply chain so as to prepare business sector and industry for entering AEC.

Human resource development in logistics in skill aspect, initially, communicative skill must be developed, especially foreign language and languages used in ASEAN, and logistics 
technical terms. Furthermore, the use of basic information technology for human resource in educational sector must be ready with skill for real operation, thus collaboration between educational institute and logistics industry should be created, so as to train the ones who are getting into labor market. Later, public sector should establish research center as a consultant for logistics system in business sector and industry; and collect data of skills which are necessary for logistics profession in human resource development application. After that, create national standard for skilled labor in logistics for encouraging labor to be interested and see importance of self-improvement and skill improvement to meet the standard.

TABLE III: MEANS FOR HuMAN RESOURCE DEVELOPMENT IN LOGISTICS

\begin{tabular}{cl}
\hline \hline \multirow{2}{*}{ Educational institute } & $\begin{array}{l}\text {-Improve teaching system to correspond to the need of labor market. } \\
\text {-Improve logistics program to reach international standard. }\end{array}$ \\
\hline \multirow{2}{*}{ Language and information technology } & $\begin{array}{l}\text {-Improve using language of personnel in logistics } \\
\text {-Promote technology learning which corresponds to national infrastructure development }\end{array}$ \\
\hline \multirow{2}{*}{ Professional standard } & $\begin{array}{l}\text {-Create standard skill for labor in logistics } \\
\text { Efficiency of labor }\end{array}$ \\
\hline \multirow{2}{*}{-Create logistics professional standard which is accepted internationally } \\
\hline
\end{tabular}

TABLE IV: SHORT-TERM

\begin{tabular}{cl}
\hline \hline \multirow{2}{*}{ Knowledge } & $\begin{array}{l}\text { Tncrease potential in short-term training, especially operation group } \\
\text {-Encourage entrepreneurs or chief executives understand logistics system }\end{array}$ \\
\hline \multirow{2}{*}{ Skill } & $\begin{array}{l}\text {-Improve foreign language skill, especially ASEAN language, general communicative skill, and technical terms of logistics, and using } \\
\text { computer } \\
\text {-Collaboration among educational institutes and entrepreneurs, organize internship for students. }\end{array}$ \\
\hline Institute & $\begin{array}{l}\text {-Develop modern curriculum which corresponds to national infrastructure development such as rail system engineering, logistics operation, } \\
\text { and international business. }\end{array}$ \\
Instructor & -Create E-Learning system relating logistics and supply chain. \\
Profession & -Create standard of curriculum in the same direction which can be transferred to other institute. \\
& -Create standard for curriculum at graduate level. \\
& -Create database of logistics personnel
\end{tabular}

TABLE V: MEDIUM-TERM

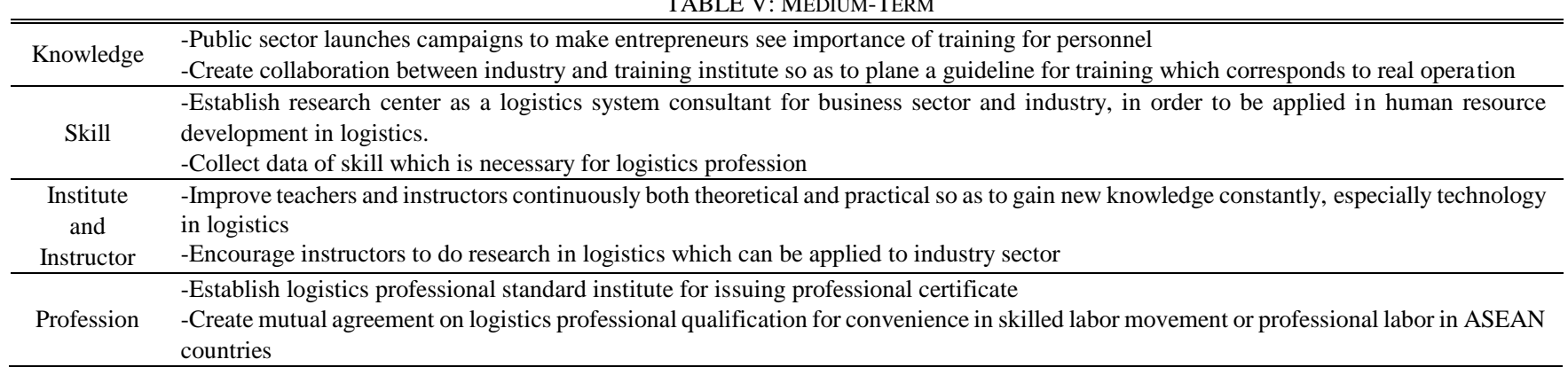

TABLE VI: LONG-TERM

\begin{tabular}{cl}
\hline \hline TABLE VI: LONG-TERM \\
\hline Knowledge & $\begin{array}{c}\text {-Encourage entrepreneurs know about law and regulations relating logistics } \\
\text {-Support introducing logistics knowledge and supply chain }\end{array}$ \\
\hline Skill & -Create national standard for skilled labor in logistics for supporting national infrastructure development \\
\hline $\begin{array}{c}\text { Institute } \\
\text { and }\end{array}$ & -Give scholarship to Master's degree and Doctoral degree students directly. \\
Instructor & -Promote research publication in logistics and be able to access research with no limitation both domestic and international \\
\hline Profession & -Work with international professional association in issuing ASEAN professional certificate \\
\hline
\end{tabular}

In educational institute and instructor aspect, they are main organization for producing human resource in logistics. Educational institutes have logistics program and related programs need to improve their curriculum for supporting the changes of economic system and country development, and creating E-Learning system in logistics and supply chain as a tool for improving learning logistics system and supply chain for learners. It would increase potential, knowledge, analyzing ability, and problem solving through different models. On the other hand, instructors need to be improved both theoretical and practical, in order to possess modern knowledge, especially logistics technology, and encourage instructors to do research on logistics which can be applied to industrial sector. It would lead to logistics system development in industrial sector. Moreover, instructors should be encouraged to improve themselves continuously by giving scholarship in logistics program. Finally, in order to do further study and apply research to real operation, instructors should be encouraged to publish their research in logistics and access national and international research with no limitation.

Human resource development in profession aspect. According to the various standards relating human resource development in logistics, it was found that educational sector should create standard for curriculum which can be connected and transferred, and create standard for logistics curriculum at graduate level, in order to be a guideline for teaching. Furthermore, database of personnel in logistics should be created for production planning and human resource development in logistics. Later, mutual agreement on qualifications of logistics profession should be created, and 
institute of logistics profession standard for issuing professional certificate should be created, in order to create advance in profession of human resource in logistics and convenience for skilled labor or professional labor movement in ASEAN countries. Development for international standard is collaboration with international professional association for issuing professional certificate in ASEAN.

Entering AEC causes logistics development in the country in information network connection, infrastructure development, and human resource development, in order to support being AEC Economic Hub of the region, which needs collaboration from public sector, private sector, and related organizations. Human resource development in logistics needs to consider human resource in business sector, industry, and educational sector, so as to correspond to human resource production in logistics and skills development. Moreover, standard for education in logistics and logistics professional standard should be created so as to create motivation for improving potential of human resource in logistics. It would increase efficiency of logistics system and competitiveness of the country. In other words, the factor for success of logistic management is human resource.

\section{REFERENCES}

[1] National Statistical Office. (2009). Transportation, public utility, and communication: Foundation of sustainable country development. [Online]. Available: www.nso.go.th/webstat/king/kfiles/k1-02.pdf

[2] P. Trairatworakun, "Economic and financial status of Thailand in ASEAN ambassadors and consul generals conference 2013," presented at Ministry of Foreign Affairs, Withetsamoson, July 15, 2013.

[3] Office of the National Economics and Social Development Board. (2013). Report of Thailand Logistics in 2012. [Online]. Available: http://www.nesdb.go.th/Portals/0/tasks/dev_logis/report/data_040220 0213.pdf

[4] W. Atthirawong, A. Wasusi, and P. Niammani, Research Synthesis in Logistics and Supply Chain in Industrial Sector. Bangkok: The Thailand Research Fund, 2011.

[5] S. Farangthong. (December 2010). Look at the future of logistics Labor. Krungthep Thurakit. [Online]. Available: http://www.bangkokbiznews.com/home/detail/politics/opinion/reader -opinion/20101203/365997

[6] A. Toemphitthayaphaisit. (2013). Personnel development/workplaces prepare for future direction. [Online]. Available: http://www.nesdb.go.th/Portals/0/tasks/dev_logis/docu/data_0154091 813.pdf
[7] N. Watthananonthachai, Personnel Development in Logistics at Graduate Level for Supporting the Growth of Logistics Service Providers of Thailand, Bangkok: King Mongkut's University of Technology Thonburi, 2005.

[8] J. Zhang, "The innovation of training model for new bonded logistics personnel," in Proc. The 19th International Conference on Industrial Engineering and Engineering Management, 2013, pp. 365-372.

[9] S. Nanthawiphawong, L. Rattanaphon, A. Banyaem, P. Chakraphisirisuk, and S. Ophasanon, "Knowledge and skill of undergraduate students in logistics program preferred by entrepreneurs," in Proc. The 7th Annual Academic Seminar on Supply Chain and Logistics Management, 2007.

[10] W. Mithom, W. Mahamit, M. Honyaem, and K. Khwannuan, "A study of placing importance on logistics of logistics program in Thailand," in Proc. Annual Academic Conference on Supply Chain and Logistics Management, 2008.

[11] Z. Yun and L. Li, "On the cultivation of job-hunting competitiveness of students in Logistics Department-Chongqing Jiao tong University in case," Advanced Technology in Teaching, Advances in Intelligent and Soft Computing, vol. 163, no. 2013, pp. 69-74, 2013.

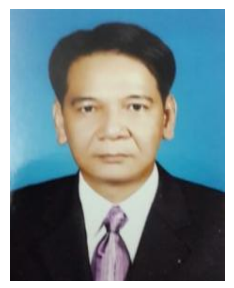

Putjai Indranoi was born in Suphanburi, Thailand on January 30, 1965. He obtained the master degree from Suan Dusit Rajabhat University, Thailand, 2003, in the field of education management.

He currently works as a cabin attendant at the Thai Air way International Public Company.

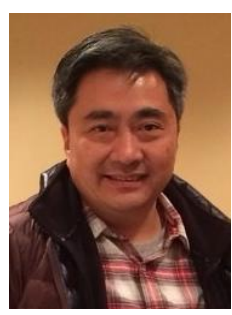

Nattaphan Kecharananta was born in Bangkok, Thailand. He had such diverse background from engineering, economics, business management and IT. Dr Nattaphan obtained his Ph.D. degree from Alliant International University, USA, 1995 in the field of leadership and human behaviors.

$\mathrm{He}$ currently works as a director of doctoral program in business management and teaches at the Graduate School, Suan Dusit Rajabhat University, Bangkok Thailand. He also supervises students dissertation in doctoral level in various universities but mainly Suan Dusit Rajabhat University. Moreover, he was invited as an adjunct professor to teach many universities such as: Chulalongkorn University; Thammasat University; King Mongkut's University of Technology Thonburi; King Mongkut's University of Technology North Bangkok; Maejo University; Ramkhamhaeng University and Rajamangala University of Technology Lanna. His research interests were on business, management, industrial economics and human resources. 